\title{
DIABETES MELLITUS TREATMENT: A RAPID REVIEW ON INNOVATIVE THERAPIES
}

\author{
D. KRISHNA VENI*, N. VISHAL GUPTA
}

Department of Pharmaceutics, JSS College of Pharmacy, JSS Academy of Higher Education and Research, JSS Medical Institutions Campus, Sri Shivarathreeswara Nagara, Mysuru, 570 015, Karnataka, India. Email: krishnavenireddy129@gmail.com

Received: 04 July 2018, Revised and Accepted: 14 September 2018

ABSTRACT

Diabetes mellitus is a chronic and metabolic disorder which results from defects in a section of insulin, action of insulin, or both. Primarily drugs are used to control the symptoms and save life. Secondary aims are to prevent long-term diabetic complications and by eliminating various risk factors to increase longevity. In type I diabetes mellitus, new innovative therapies such as pancreatic transplantation, pancreatic islet transplantation, stem cell therapy, transdifferentiation, and gene therapy are discussed, and regarding type II diabetes mellitus, treatment is based on drugs which stimulates the secretion of insulin such as conventional therapy, antihypoglycemic agents such as insulin, insulin secretagogues, and insulin sensitizers, $\alpha$-glucosidase inhibitors, dipeptidyl peptidase- 4 inhibitors, and sodium-glucose cotransporter 2 inhibitors, and a list of patents for the treatment of diabetes mellitus are discussed in this review article.

Keywords: Diabetes mellitus, Hypoglycemic agents, Insulin secretagogues, Insulin sensitizers, Patents, Stem cell therapy.

(c) 2019 The Authors. Published by Innovare Academic Sciences Pvt Ltd. This is an open access article under the CC BY license (http://creativecommons. org/licenses/by/4. 0/) DOI: http://dx.doi.org/10.22159/ajpcr.2019.v12i1.28285

\section{INTRODUCTION}

\section{Diabetes mellitus}

Diabetes mellitus is a metabolic and chronic disorder which diminishes the activity of energy utilization from food by the human body for lifetime. It is a chronic metabolic disorder, which is characterized by chronic hyperglycemia, deficiency of insulin, and resistance to insulin. With diabetes mellitus, either your body loses the ability to produce insulin or there occurs improper use of the produced insulin. There are two major types of diabetes.

1. Type I diabetes mellitus (insulin-dependent diabetes mellitus [IDDM]).

2. Type II diabetes mellitus (non-insulin-dependent diabetes mellitus [NIDDM]).

\section{Type I diabetes mellitus}

It is also called insulin-dependent diabetes or juvenile diabetes. It causes autoimmune and kidney disease, heart stroke, and nerve damage to the nerves which are present in feet. In this type, diabetes body's immune system attacks its own pancreas and stops the insulin secretion. One of the reasons for this type of diabetes is a genetic predisposition. It can be also the result of faulty pancreatic $\beta$-cells. Medical risks associated with this type diabetes are damage to the small blood vessels which are present in the eyes, kidneys, and nerves.

\section{Type II diabetes mellitus}

It is also called as NIDDM and adult-onset diabetes. It is the most common and milder form of diabetes than type I diabetes mellitus. Nevertheless, it still can cause major health problems, especially the small blood vessels which are present in the eyes, nerves, and kidneys. It also increases the risk of heart diseases and heart dose. With this type II diabetes, the body's pancreas normally produces the insulin either the produced insulin is not enough or the body's cells are resistant to insulin [1-5].

\section{Pancreatic transplantation}

It is a surgical operation, and the normal pancreas is collected from an expired person and inserted into a person's body whose pancreas not works properly. Pancreatic transplantations are done to treat or control type I diabetes mellitus. The pancreas lies in the lower part of the stomach. The pancreas major function is to secrete a hormone called insulin, which regulates or controls the sugar absorption into body cells. Type I diabetes mellitus results when the pancreas does not produce sufficient insulin, causing sugar levels in the blood rise to dangerous levels.

The surgical team checks the heart rate, blood oxygen, and pressure throughout the procedure with a heart monitor leads attached to the chest and blood pressure cuff on arm of the patient.

After the patient is unconscious:

- A small cut is made the center of the patient abdomen.

- The surgeon keeps the new pancreas along with a small portion of the small intestine into the patient's lower abdomen.

- Then they will attach donor new sections of small intestine containing pancreas to patients small intestine or donor pancreas to patient urinary bladder and pancreas is connected to blood vessels.

- Do not disturb the patient's pancreas to aid digestion.

- If the patient is also receiving a kidney transplant, the blood vessels of the new kidney will be attached to the lower part of a patient's abdomen blood vessel.

- The new ureters by which urine passes from kidneys to bladder. Unless patient's own kidneys are causing major problems, such as infection or high blood pressure, they are not disturbed from their place.

Pancreas transplantation generally takes about $3 \mathrm{~h}$. Along with that kidney-pancreas transplantation takes a few more hours.

\section{Complications of the procedure}

Bleeding, blood clots, infection, urinary complications, hyperglycemia, donated organs failure, and donated organs rejection are the cpmplications of the procedure.

\section{RESULTS}

After pancreas transplantation, the new pancreas produces the insulin, so the patient does not require insulin therapy to treat type I diabetes. Even though there is compatibility between patient and the donor, patient's immune system will try to reject the new pancreas. To avoid rejection of newly transplanted pancreas, patient needs medications to suppress the body's immune system the rest of life. Patients need to take anti-rejection drugs or immunosuppressants for the rest of life. 
Immunosuppressant's or antirejection drugs

These are medicines or drugs that lower the body's ability to reject transplanted organs. These drugs are also called as anti-rejection drugs.

Immunosuppressants are categorized into:

1. Induction drugs: These are powerful anti-rejection drugs used at the time of transplant.

2. Maintenance Drugs: These drugs are used for long term

There are usually four classes of maintenance drugs:

\section{Antiproliferative agents}

Azathioprine, mycophenolate mofetil, and mycophenolate sodium.

\section{Calcineurin inhibitors}

Cyclosporine and tacrolimus.

\section{Mammalian target of rapamycin inhibitor}

Sirolimus.

Steroids

Prednisone.

\section{Transplanted pancreas and kidney survival rates are as follows: Pancreas transplantation}

In about $81 \%$ of people who undergoes pancreas transplantation, after 1 year, the transplanted pancreas is still working, and after 5 years, that rate of working is up to $53 \%$.

\section{Simultaneous pancreas and kidney transplantation}

In about $90 \%$ of people who receive simultaneous pancreas-kidney transplantation, after 1 year, the transplanted kidney and pancreas are still working, and after 5 years, the rate of working is up to $78 \%$.

\section{Pancreas transplantation after kidney transplantation}

In about $87 \%$ of people who receive pancreas transplantation after kidney transplantation, after 1 year, the transplanted pancreas is still working, and after 5 years, the rate of working is up to $70 \%$.

\section{Diet}

No dietary restrictions are required after pancreatic transplantation.

\section{Pancreatic islets}

It is also called as islets of Langerhans; these are the minute clusters of cells which are dispersed throughout the pancreas.

It consists of numerous types of cells including $\beta$-cells, pancreatic $\beta$-cells which produces the insulin hormone, and enzymes which help the body to digest food.

When the blood glucose or blood sugar levels increase after a meal, the pancreas will release insulin into the bloodstream. Insulin is required for absorption of glucose from the bloodstream and for conversion of glucose into energy.

In type I diabetes, pancreatic $\beta$-cells does not produce insulin because the body's immune system attacks its own pancreas and stops secreting the insulin. Due to this situation, blood glucose levels will increase instead of being absorbed by the body cells. People who have type I diabetes should take insulin daily to live and to maintain the blood sugar levels normal.

\section{Pancreatic islet transplantation}

There are two types of pancreatic islet transplantations which are available:
- Allotransplantation

- Autotransplantation.

\section{Pancreatic islet allotransplantation}

It is a procedure in which islets from a deceased donor pancreas are purified and transferred into a patient. In pancreatic islet allotransplantation to remove islets from a diseased donor, they use specialized enzymes. Then, the collected islets are purified and counted in the laboratory. A patient receives two transplantations with an average of 500,000-600,000 islets per each transplantation. After implantation, the $\beta$-cells in the islets start to release insulin. This type of transplantation is performed in patients whose type I diabetes levels are high and difficult to control. The main aim of this transplantation is to help the patients achieve normal glucose levels without daily insulin injections and eliminate hypoglycemia.

Pancreatic islet transplantation carried out only at hospitals which have USFDA authorization for clinical research on pancreatic islet transplantation. The radiologist performs these transplants frequently. The radiologist uses ultrasound and X-rays to guide the catheter through a small incision in the upper abdomen. Then, pancreatic islets are then infused through the catheter slowly into the liver. Usually, a patient receives a sedative and local anesthetic. In few cases, a surgeon performs the pancreatic islet transplantation by using general anesthesia. Patients regularly need two or more transplants to get a sufficient amount of islets to reduce or stop their need for insulin.

\section{Pancreatic islet autotransplantation}

In patients with chronic, long-lasting, and severe pancreatitis, which can be accomplished only by pancreatic islet autotransplantation, the procedure of pancreatectomy is carried out. Pancreatic islet autotransplantation cannot be carried out in the patients with type I diabetes. It is carried out in the hospital and the surgeon will administer general anesthesia to the patient. First and foremost, surgeon will remove the pancreas, followed by pancreatic islets extraction and purification. Using catheter, the islets are infused into the liver of the patient. Then, the infused islets will secrete the insulin which maintains the blood glucose levels.

The advantages of pancreatic islet autotransplantation are an improvement in control of the blood glucose levels and reduce the need for insulin injections to control the blood glucose levels and hindrance of hyperglycemia. Whole pancreas transplantation is the alternative for this method, which is performed along with the kidney transplantation. Whole pancreas transplantation benefits are less dependent on insulin and longer duration of pancreas function. The main drawbacks with the whole pancreas transplantation are major surgery, which involves major risk of complications.

Immunosuppressive or anti-rejection medications are needed to avoid the rejection, and it is a common problem associated with transplantation

Immunosuppressive or anti-rejection medications are tacrolimus, sirolimus, and daclizumab. For example, immunosuppressive drugs used in islet transplantation contain alemtuzumab, anti-thymocyte globulin, basiliximab, belatacept, etanercept, everolimus, and mycophenolate mofetil.

Anti-rejection medications have immediate side effects which may include gastrointestinal problems, mouth sores, and stomach upset and risk of developing certain tumors and cancers (Fig. 1).

\section{Diet and nutrition}

The person who undergoes pancreatic transplantation should follow a particular diet suggested by the dietician or a health-care provider [6-20].

\section{Stem cells}

It is an alternative for transplantable $\beta$-cells. These stem cells have a remarkable capacity to develop into different cell types in the body. It 
acts as an internal repair system in many tissues. When the division of stem cells occurs, each divided new cell has the capacity to remain as a stem cell or become different types of cell with a more specific function such as brain cells, muscle cells, and red blood cells (Fig. 2).

Stem cells are available in two potential sources:

1. Embryonic stem cells (ES).

2. Induced pluripotential stem cells.

\section{ES cells}

ES cells, induced pluripotent stem cells, and pancreas-derived stem cells are able to distinguish into beta-cells. Hepatic stem cell expressing pancreatic and duodenal homeobox-1 (PDX-1) distinguished into $\beta$-cells and improves excessive glucose levels in the blood of diabetic mice. ES cells are separated from blastocysts, and it can be distinguished into ectoderm, endoderm, and mesoderm cells. They can also distinguish into insulin-producing cells, and these cells are able to secrete insulin in response to glucose stimuli and to regularize the glucose levels in the blood of diabetic mice when it transferred into diabetic mice (Fig. 3)

The stem cell production from a pluripotent resource is called as induced pluripotency. For the production of pluripotent stem cells, somatic stem cells are reprogrammed under specific conditions; such type of cells is called as induced pluripotent stem cells. These cells exhibit rises in the activity which is similar to ES cells. These are preferred as the best choice for the cell-based treatment for diabetes mellitus. For the production of Induced pluripotent stem cells (IPSC), fibroblast cells are induced and later these cells are converted into pancreatic $\beta$-cells. The transferring of fibroblast-derived $\beta$-cells into diabetic mouse controlled the blood glucose levels [21-26] (Fig. 4).

\section{Transdifferentiation}

Patients fibroblasts transdifferentiation into pancreatic like cells might render most straight forward clinical application of reprogrammed cells based therapy without the concerns of HESC (human embryonic stem

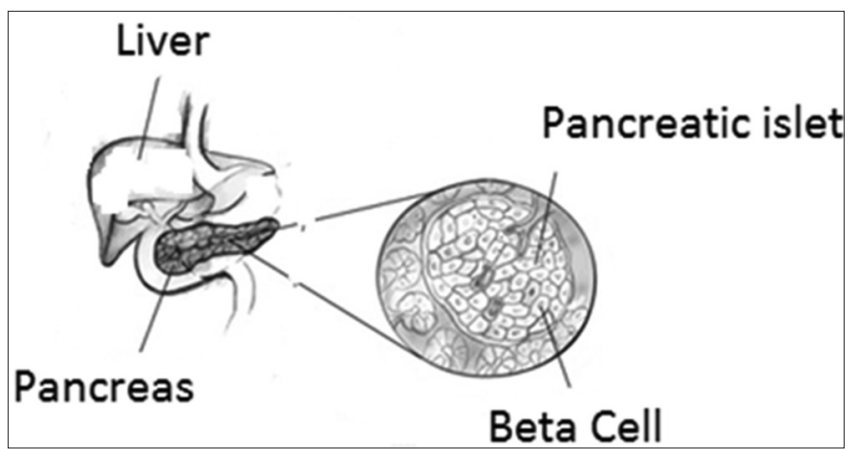

Fig. 1: Pancreatic islet transplantation

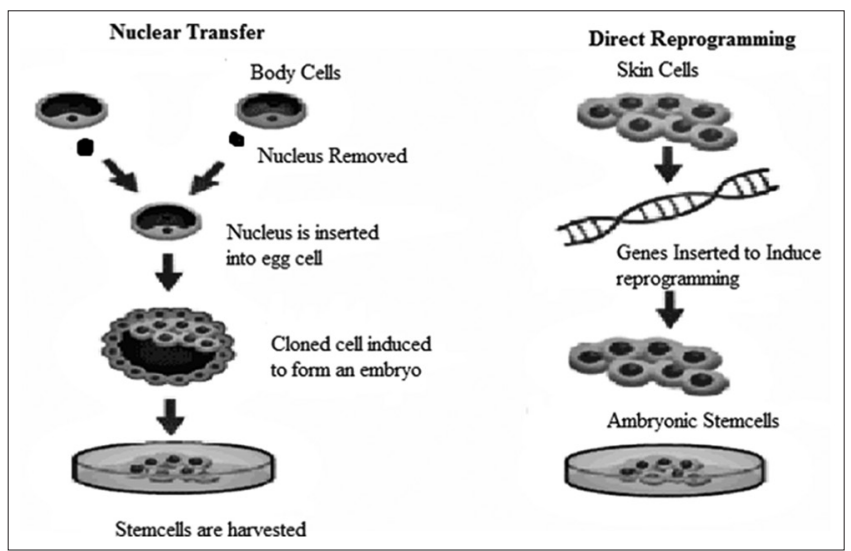

Fig. 2: Stem cell transplantation cells) or with HIPSC (human induced pluripotent stem cells). For cell replacement therapy, transdifferentiation has become the tendency to produce $\beta$-cell resources. This method depends on cellular reprogramming and regeneration of $\beta$-cells. Regeneration of $\beta$-cells will occur from different pancreatic progenitor cells in the grown person pancreas. Acinar ductal transdifferentiation is a mechanism by which acinar cells are distinguished into duct cells. In addition to this, acinar cells have the capability to distinguish into adipocytes and hepatocyte-like cells, controlled by the microenvironment. $\alpha$-cells have the ability to convert into $\beta$-cells in zebrafish by utilizing $\beta$-cell ablation model. Glucagon and glucagon-like peptide-1 (GLP-1) have a strong effect on $\alpha$-to- $\beta$ cell transdifferentiation, and $\beta$-to- $\alpha$ cell transdifferentiation is also feasible in the case of opposition. Suppression of pancreatic duodenal homeo box 1, forkhead box 01, NK2 homeobox 2 and transdifferentiated into $\alpha$-cells and induced the dedifferentiation of $\beta$-cells. $\delta$-cells of the pancreas are capable of transdifferentiate into insulin-producing cells [27-35] (Fig. 5).

\section{Gene therapy}

A foreign gene is introduced into any cell type in the body, permitting it to produce insulin which is called as gene therapy. The introduced gene would be either insulin gene itself or a gene encoding factor which activates the insulin gene, thereby allowing the ectopic production of insulin. Differentiation of stem cell into $\beta$-cells in the patient by means of molecular intervention would be included in this gene therapy.

\section{Cell replacement therapy}

One of the most potent therapies for diabetes mellitus is cell replacement therapy of insulin-producing cells. This therapy includes the islet cell transplantation contributed by the pancreas of the donor; these cells

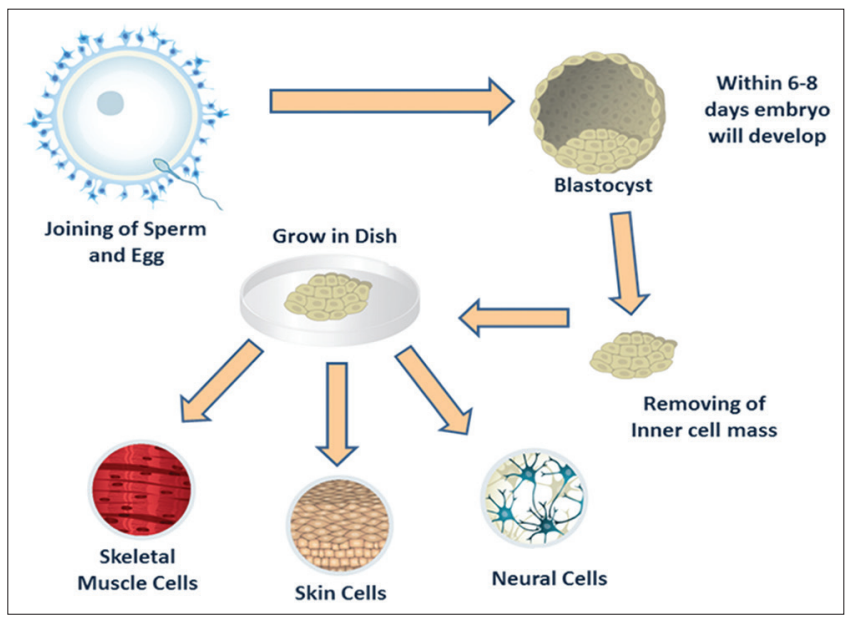

Fig. 3: Embryonic stem cells

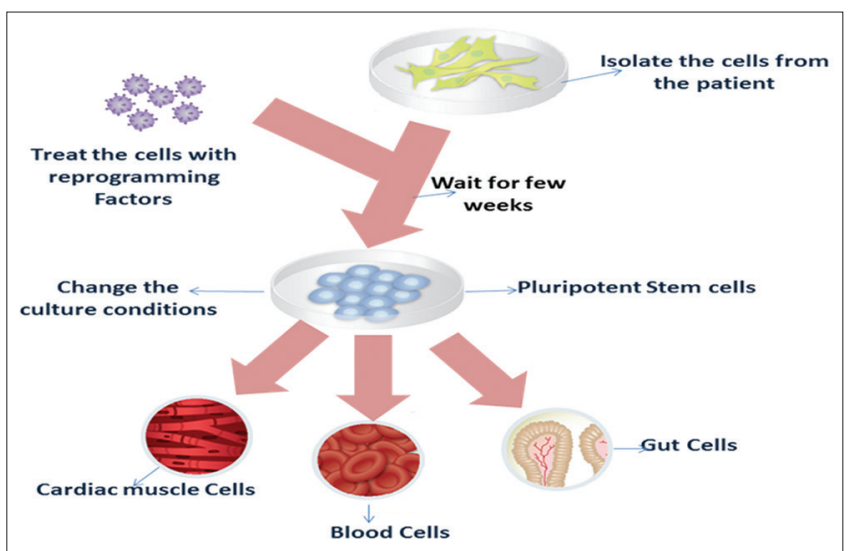

Fig. 4: Induced pluripotential stem cells 


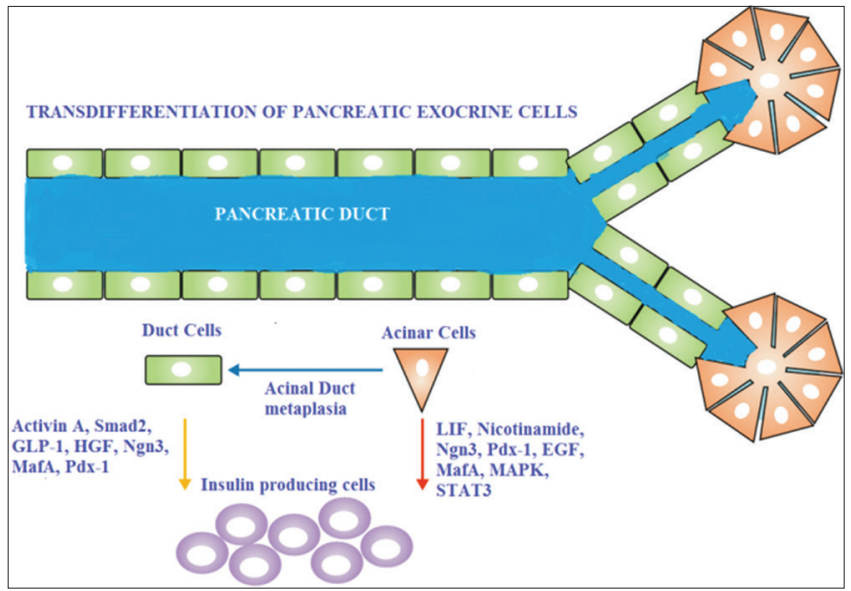

Fig. 5: Transdifferentiation of pancreatic exocrine cells

will function for years in diabetic patients. Cell replacement therapy encompasses all techniques that involve the expansion or creation of in vitro insulin-producing cells followed by their implantation in the patient. The cells can be from beta origin, may be immortalized to permit absolute expansion in culture, or manipulate the non-beta-cells to produce insulin. On the other hand, they can be originated from stem cells [29,35-40].

\section{Treatment for type II diabetes mellitus}

Antihypoglycemic agents

- Insulin

- Insulin secretagogues

- Sulfonylureas

- Meglitinides.

- Insulin sensitizers

- Metformin $\mathrm{HCl}$

- Thiazolidinedione

- $\quad \alpha$-glucosidase inhibitors (AGI)

- Dipeptidyl peptidase-4 (DPP-4) inhibitors

- Sodium-glucose cotransporter-2 (SGLT2) inhibitors.

Insulin

People who have IDDM cannot formulate insulin because of the damaged or ruined $\beta$-cells in their pancreas. For that reason, patients who have type I diabetes will need insulin injections to allow their body to process glucose and to avoid complications from hyperglycemia.

\section{Insulin types}

There are different types of insulins. It categorized from rapid acting to long-acting insulins, from analog insulin through to human insulins. Insulin can be categorized based on how the insulin is derived and how quickly it works.

\section{Forms of insulin}

There are three forms of insulin which are available.

1. Analog insulin: Analog insulin is a laboratory-grown human insulin.

2. Animal insulin: Animal insulin comes from animals.

3. Human insulin: Human insulin is laboratory-made insulin.

\section{Insulin is administered by two routes (Fig. 6)}

1. Injetion

2. Infusion

\section{Injection}

Insulin syringe

This is a regular method for insulin delivery. In this method, insulin syringe is an injection device. The disposable, plastic syringes currently

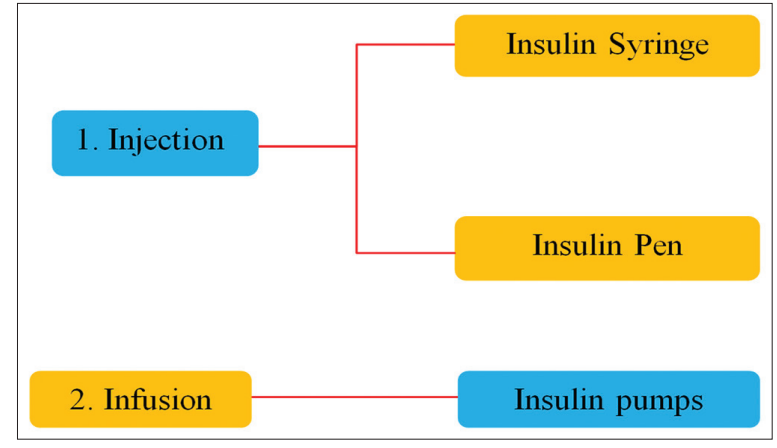

Fig. 6: Routes of insulin administration

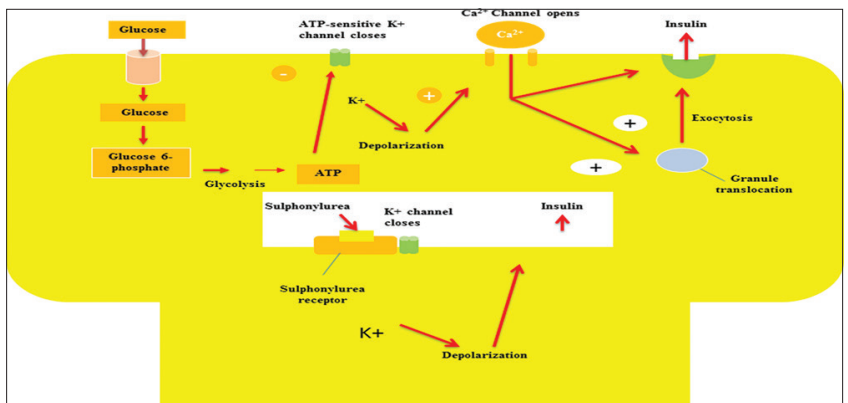

Fig. 7: Mechanism of the action of sulfonylureas

are available in three sizes as 30,50 , and 100 units of insulin. The needles are fine with the length ranging from $1 / 2$ inch or more for adults and $3 / 16^{\text {th }}$ of an inch for infants. This syringe is injected into the layer of fat just below the skin.

\section{Insulin pen}

There are two types of insulin pens which are available.

1. Reusable pens

2. Disposable pens

\section{Reusable pens}

The reusable pen is loaded with a cartridge of insulin before its use. 150-300 units of insulin can be held in one cartridge. A cartridge may provide sufficient insulin based on the size of your dose which may last for many days. A new cartridge can be loaded after the usage of the previous one reusable pen can be used generally for many years.

\section{Disposable pens}

Disposable pens are filled with insulin and discarded after its use. 300 units of insulin can be held in most of the disposable insulin pens which are more convenient than the reusable pens because no need of filling any cartridges. These are most costlier compared to reusable pens.

\section{Infusion}

In a hospital under the medical supervision, insulin may be injected directly into the vein. It is added to intravenous fluids, blood sugar, and insulin doses which are strictly monitored by the specialists. It is only given during the surgery or stay in the intensive care unit.

\section{Insulin pump}

It is also known as continuous subcutaneous insulin infusion device. These are the most sophisticated form of insulin delivery. Insulin pumps are computerized devices, small in size that is programmed to transport insulin under the skin. These are durable and last for many years, but certain components of the insulin pump and the insulin supply are changed every few days. 
Insulin secretagogues

These are one type of medicine used for type II diabetes treatment. A person with type II diabetes does not make sufficient insulin or body cells have insulin resistance. In that condition, insulin secretagogues help the pancreas to secrete or release insulin. Insulin helps to maintain blood glucose levels normal.

\section{Sulfonylureas}

These are the first oral medicine available for the treatment of type II diabetes mellitus. For diabetes treatment, carbutamide is the first clinically useful sulfonylurea [36,41-43].

\section{Types of sulfonylureas}

- First-generation sulfonylureas.

- Second-generation sulfonylureas. Drugs comes under sulfonylureas are given in table 1

- $\quad$ Third-generation sulfonylureas.

\section{Mechanism of action}

By stimulating the pancreas to more insulin release, these are effective only when the $\beta$-cell activity is still present. It blocks the adenosine triphosphate (ATP)-sensitive $\mathrm{K}+$ channels in $\beta$-cells and decreases the $\mathrm{K}$ permeability of $\beta$-cells. This action causes the $\mathrm{Ca}^{+2}$ entry into the cell and depolarization of the cells, which causes improvement in the secretion of the insulin. The released insulin will reduce the blood glucose levels [41,42,44-47] (Fig. 7).

Table 1: Drugs used in sulfonylureas

\begin{tabular}{lll}
\hline $\begin{array}{l}\text { First-generation } \\
\text { sulfonylureas }\end{array}$ & $\begin{array}{l}\text { Second-generation } \\
\text { generation sulfonylureas }\end{array}$ & $\begin{array}{l}\text { Third-generation } \\
\text { sulfonylureas }\end{array}$ \\
\hline Acetohexamide & Glibenclamide & Glimepiride \\
Chlorpropamide & $\begin{array}{l}\text { Gliclazide } \\
\text { Tolazamide }\end{array}$ & $\begin{array}{l}\text { Glyclopyramide } \\
\text { Tolbutamide }\end{array}$ \\
& $\begin{array}{l}\text { Glipizide } \\
\text { Gliquidone }\end{array}$ & \\
\hline
\end{tabular}

Table 2: Drugs used in meglitinide category

\begin{tabular}{ll}
\hline Generic name & Brand name \\
\hline Repaglinide & Prandin \\
Nateglinide & Starlix \\
\hline
\end{tabular}

Table 3: Drugs used in thiazolidinedione category

\begin{tabular}{ll}
\hline Generic name & Brand name \\
\hline Rosiglitazone & Avandia \\
Pioglitazone & Actos \\
\hline
\end{tabular}

Table 4: Drugs used in AGI category

\begin{tabular}{ll}
\hline Generic name & Brand name \\
\hline Acarbose & Precose \\
Miglitol & Glyset \\
\hline
\end{tabular}

AGI: $\alpha$-glucosidase inhibitor

Table 5: Drugs used in DPP-4 inhibitor category

\begin{tabular}{ll}
\hline Generic name & Brand name \\
\hline Sitagliptin & Januvia \\
Vildagliptin & Galvus \\
Saxagliptin & Onglyza \\
Linagliptin & Tradjenta \\
\hline
\end{tabular}

DPP-4: Dipeptidyl peptidase-4

\section{Meglitinides}

These are oral medicines utilized for the treatment of type II diabetes mellitus. Meglitinides work similarly as sulfonylureas. It reduces the blood glucose levels by increasing the secretion of insulin by the pancreas. These are fast acting and disperse quickly, so they frequently must be taken many times a day.

Currently, two forms of meglitinides are available in the market (Table 2).

\section{Mechanism of action}

It stimulates the pancreatic insulin secretion and, after meals, reduces the glucose levels rise in the blood [48-53]

\section{Insulin sensitizers \\ Biguanides}

This is one of the classes of medications used for the treatment of type II diabetes mellitus. It starts to lower the blood glucose by two ways. Primarily, it starts to decrease the amount of glucose produced by the liver. It increases the glucose absorption by muscle cell and reduces the insulin resistance.

The only drug used in biguanides is metformin

Table 6: Drugs used in SGLT2 inhibitors

\begin{tabular}{ll}
\hline Generic name & Brand name \\
\hline Canagliflozin & Invokana \\
Dapagliflozin & Farxiga \\
Empagliflozin & Jardiance \\
\hline
\end{tabular}

SGLT2: Sodium-glucose cotransporter-2

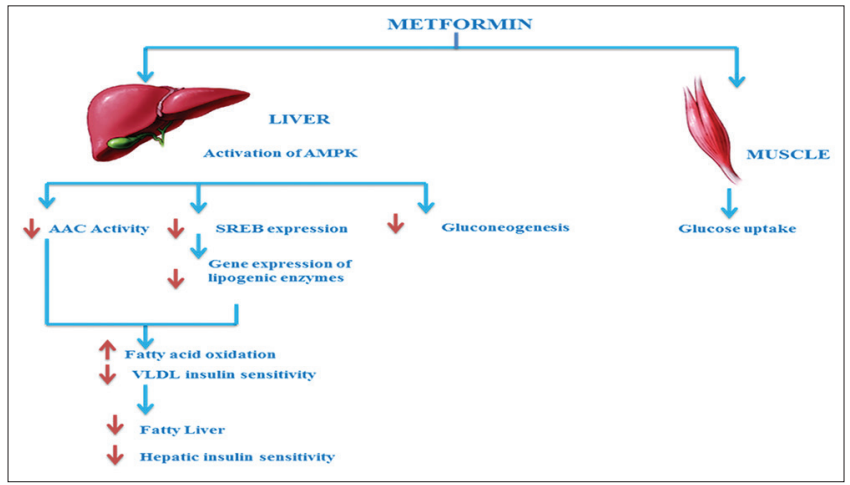

Fig. 8: Mechanism of the action of metformin

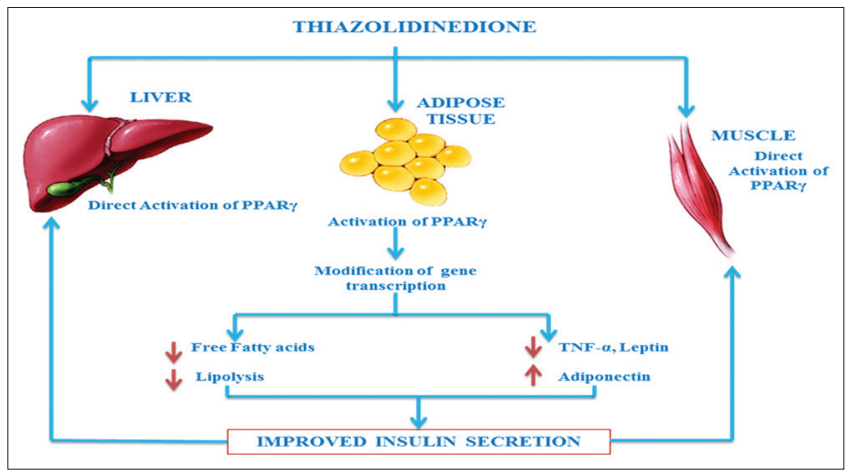

Fig. 9: Mechanism of action of thiazolidinedione 


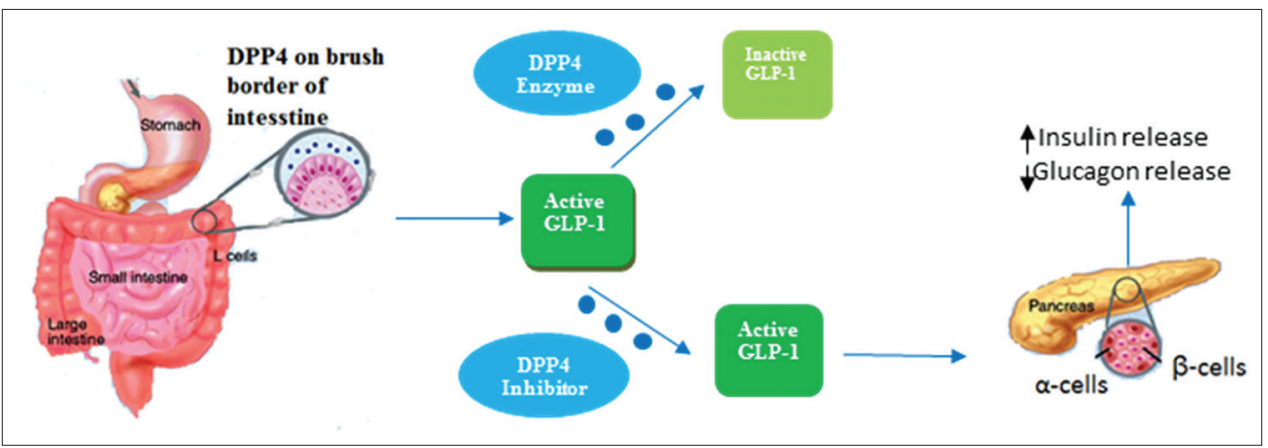

Fig. 10: Mechanism of the action of dipeptidyl peptidase-4 inhibitors

Table 7: List of patents in the treatment of diabetes

\begin{tabular}{|c|c|c|c|c|}
\hline Title & Patent No. & Inventors & Year & References \\
\hline $\begin{array}{l}\text { Substituted aromatic compounds } \\
\text { and pharmaceutical compositions } \\
\text { for the prevention and treatment } \\
\text { of diabetes }\end{array}$ & W02016054726 A1 & Gagnon et al. & April 14, 2016 & $\begin{array}{l}\text { Substituted aromatic compounds and } \\
\text { pharmaceutical compositions for the } \\
\text { prevention and treatment of diabetes, } \\
\text { W02016054726 A1, April 14, } 2016\end{array}$ \\
\hline $\begin{array}{l}\text { DPP-4 inhibitor combined with a } \\
\text { further antidiabetic agent, tablets } \\
\text { compromising such formulations, } \\
\text { their use, and process for their } \\
\text { preparation }\end{array}$ & US9155705 B2 & Friedl et al. & October13, 2015 & $\begin{array}{l}\text { Friedl et al. DPP- } 4 \text { inhibitor combined } \\
\text { with a further antidiabetic agent, tablets } \\
\text { compromising such formulations, their } \\
\text { use, and process for their preparation, } \\
\text { US9155705 B2, } 2015\end{array}$ \\
\hline Diabetes therapy & US9149478 B2 & Klein et al. & October 06, 2015 & $\begin{array}{l}\text { Klein et al. Diabetes Therapy, } \\
\text { US9149478B } 2,6^{\text {th }} \text { Oct } 2015\end{array}$ \\
\hline $\begin{array}{l}\text { Vasoprotective and } \\
\text { cardioprotective antidiabetic } \\
\text { therapy }\end{array}$ & US9034883 B2 & Klein et al. & May, 192015 & $\begin{array}{l}\text { Vasoprotective and cardioprotective } \\
\text { antidiabetic therapy, US9034883 B2, 19, } \\
\text { May } 2015 .\end{array}$ \\
\hline $\begin{array}{l}\text { Combination therapy for the } \\
\text { treatment of diabetes and related } \\
\text { conditions }\end{array}$ & US8513264 B2 & Mark et al. & August 20, 2013 & $\begin{array}{l}\text { Combination therapy for the treatment of } \\
\text { diabetes and related conditions, US8513264 } \\
\text { B2, August 20,2013 }\end{array}$ \\
\hline $\begin{array}{l}\text { Heterocyclic receptoragonist for } \\
\text { the treatment of diabetes and } \\
\text { related conditions }\end{array}$ & US8288384 B2 & Chen et al. & October 16, 2012 & $\begin{array}{l}\text { Heterocyclic receptoragonist for the } \\
\text { treatment of diabetes and related conditions, } \\
\text { US8288384 B2, October } 16,2012\end{array}$ \\
\hline Uses of DPP-4 inhibitors & US8232281 B2 & Klaus et al. & July 31, 2012 & $\begin{array}{l}\text { Uses of DPP-4 inhibitors, US8232281 B2, } \\
\text { July 31, } 2012\end{array}$ \\
\hline $\begin{array}{l}\mathrm{N} \text {-linked heterocyclic receptor } \\
\text { agonists for the treatment of } \\
\text { diabetes and metabolic disorders }\end{array}$ & US8183381 B2 & Ma and Rabbat & May 22, 2012 & $\begin{array}{l}\text { N-linked heterocyclic receptor agonists for } \\
\text { the treatment of diabetes and metabolic } \\
\text { disorders, US8183381 B2, May 22, } 2012\end{array}$ \\
\hline $\begin{array}{l}\text { System and method for } \\
\text { distinguishing among cardiac } \\
\text { ischemia, hypoglycemia, } \\
\text { and hyperglycemia using an } \\
\text { implantable medical device }\end{array}$ & US8180441 B2 & Gill et al. & May 15, 2012 & $\begin{array}{l}\text { System and method for distinguishing } \\
\text { among cardiac ischemia, hypoglycemia, and } \\
\text { hyperglycemia using an implantable medical } \\
\text { device, US8180441 B2, May 15, } 2012\end{array}$ \\
\hline $\begin{array}{l}\text { Neural stimulation for treatment } \\
\text { of metabolic syndrome and type II } \\
\text { diabetes }\end{array}$ & US7689277 B2 & Dobak III & March 30, 2010 & $\begin{array}{l}\text { Neural stimulation for the treatment of } \\
\text { metabolic syndrome and type II diabetes, } \\
\text { US7689277 B2, March 30, } 2010\end{array}$ \\
\hline
\end{tabular}

DPP-4: Dipeptidyl peptidase-4

\section{Metformin}

\section{Mechanism of action}

Metformin starts its action in two ways. Primarily, it helps to stop the production of new glucose from the liver. It also helps to control the insulin sensitivity by transporting the glucose into cells effectively (Fig. 8).

\section{Thiazolidinediones}

These are new form of drugs for type II diabetes treatment (Table 3).

\section{Mechanism of action}

It reduces the blood sugar levels by increasing the fat, liver, and muscle sensitivity to insulin. These are referred as insulin sensitizers or euglycemic. It will take the time to show their therapeutic action. The main side effects of this drugs are fluid retention, weight gain, and anemia [54-58] (Fig. 9).

AGI

These are widely used in type II diabetes treatment. It delays the carbohydrate absorption from the small intestine and reduces the 
postprandial blood glucose levels and insulin levels.

Drugs come under AGIs which are given in Table 4.

AGIs reversibly hinder a number of $\alpha$-glucosidase enzymes, consequently delaying the absorption of glucose from the gut. The therapeutic effects of AGI are not only based on a delayed complex carbohydrate digestion but also on the metabolic effects of colonic starch fermentation. Acarbose is the most widely prescribed AGI. The other AGIs are voglibose and miglitol [59-63].

\section{Novel antidiabetic agents}

DPP-4 inhibitors

DPP4 inhibitors are a class of oral hypoglycemic agents which block DPP4 enzyme secreted by brush border of the intestine. These are used for type II diabetes treatment (Table 4)

\section{Mechanism of action}

GLP-1 and incretin secreted by the small intestine. DPP4 enzyme stops the GLP-1and incretin release. DPP4 inhibitors inhibit the DPP4 enzyme production, and because of this action, GLP-1 and incretin production increase in the body. GLP-1 increases the insulin production by inhibiting the glucagon release and reduces the blood sugar levels [64-69] (Fig. 10).

\section{SGLT2 inhibitors}

\section{Mechanism of action}

SGLT2 inhibitors are the latest class of oral hypoglycemic agents for type II diabetes mellitus treatment (Table 6).

SGLT2 inhibitor blocks the SGLT2 protein involved in the reabsorption of glucose up to $90 \%$ in the proximal renal tubule. It results in increased excretion of the glucose from renal tube and lowers glucose level in the blood. These also increase the insulin sensitivity, decrease gluconeogenesis, and improve insulin release from pancreatic $\beta$-cells [70-75] currently available patents are presented in (Table 7).

\section{CONCLUSION}

Diabetes mellitus is a slow killer with no curable treatments. On the other hand, its complications can be cut down through proper understanding and appropriate treatment. Three major complications are related to heart attack, kidney damage, and blindness. It is necessary to keep that the blood sugar levels of a patient should be normal to avoid any complications. One of the disadvantages by keeping the blood glucose level will lead to hyperglycemia that creates many severe complications. The objective of this article is to provide an idea about the current status of diabetes mellitus research and innovative therapies for the cure.

\section{AUTHORS' CONTRIBUTIONS}

All the authors have contributed equally.

\section{CONFLICTS OF INTEREST}

There are no conflicts of interest between authors.

\section{REFERENCES}

1. El-Kaissi S, Sherbeeni S. Pharmacological management of Type 2 diabetes mellitus: An update. Curr Diabetes Rev 2011;7:392-5.

2. The Diabetes Control and Complications Trial Research Group. Adverse events and their association with treatment regimens in the diabetes control and complications trial. Diabetes Care 1995;18:1415-27.

3. Vijayan M, Jose R, Jose S, Abraham S, Joy J. Study on quality of life assessment in diabetic retinopathy among patients with type 2 diabetic patients. Asian J Pharm Clin Res 2017;10:116-119.

4. Muhas C, Naseef P. A review article-gestational diabetes mellitus. Int J Curr Pharm Res 2017;9:1-5.

5. Furth ME, Atala A. Stem cell sources to treat diabetes. J Cell Biochem 2009;106:507-11.
6. Couri CE, Voltarelli JC. Autologous stem cell transplantation forearly Type 1 diabetes mellitus. Autoimmunity 2008;41:666-72.

7. Gross CR, Limwattananon C, Matthees BJ. Quality of life after pancreas transplantation: A review. Clin Transplant 1998;12:351-61.

8. Demartines N, Schiesser M, Clavien PA. An evidence-based analysis of simultaneous pancreas-kidney and pancreas transplantation alone. Am J Transplant 2005;5:2688-97.

9. Burke GW $3^{\text {rd }}$, Vendrame F, Virdi SK, Ciancio G, Chen L, Ruiz P, et al. Lessons from pancreas transplantation in Type 1 diabetes: Recurrence of islet autoimmunity. Curr Diab Rep 2015;15:121-2.

10. Kerr HR, Hatipoglu B, Krishnamurthi V. Pancreas transplant for diabetes mellitus. Cleve Clin J Med 2015;82:738-44.

11. Ziaja J, Bozek-Pajak D, Kowalik A, Krol R, Cierpka L. Impact of pancreas transplantation on the quality of life of diabetic renal transplant recipients. Transplant Proc 2009;41:3156-8.

12. Decker E, Coimbra C, Weekers L. A retrospective monocenter review of simultaneous pancreas-kidney transplantation. Transplant Proc 2009;41:3389-92.

13. Becker LE, Hallscheidt P, Schaefer SM, Klein K, Grenacher L, Waldherr R. A single-center experience on the value of pancreas graft biopsies and HLA antibody monitoring after simultaneous pancreas kidney transplantation. Transplant Proc 2015;47:2504-12.

14. Redfield RR, Scalea JR, Odorico JS. Simultaneous pancreas and kidney transplantation: Current trends and future directions. Curr Opin Organ Transplant 2015;20:94-102.

15. McCullough KP, Keith DS, Meyer KH, Stock PG, Brayman KL, Leichtman AB. Kidney and pancreas transplantation in the United States, 1998-2007: Access for patients with diabetes and end-stage renal disease. Am J Transplant 2009;9:894-6.

16. Sampaio MS, Poommipanit N, Cho YW, Shah T, Bunnapradist S. Transplantation with pancreas after living donor kidney vs. living donor kidney alone in Type 1 diabetes mellitus recipients. Clin Transplant 2010;24:812-20.

17. Schenker P, Vonend O, Krüger B, Klein T, Michalski S, Wunsch A, et al. Long-term results of pancreas transplantation in patients older than 50 years. Transpl Int 2011;24:136-42.

18. Drachenberg CB, Odorico J, Demetris AJ, Arend L, Bajema IM, Bruijn JA, et al. Banff schema for grading pancreas allograft rejection: Working proposal by a multi-disciplinary international consensus panel. Am J Transplant 2008;8:1237-49.

19. Mora M, Ricart MJ, Casamitjana R, Astudillo E, López I, Jiménez A, et al. Pancreas and kidney transplantation: Long-term endocrine function. Clin Transplant 2010;24:236-40.

20. Ojo AO, Meier-Kriesche HU, Hanson JA, Leichtman A, Magee JC, Cibrik D, et al. The impact of simultaneous pancreas-kidney transplantation on long-term patient survival. Transplantation 2001;71:82-90.

21. Gruessner AC, Sutherland DE. Pancreas transplant outcomes for United States and non-US cases as reported to the United network for organ sharing and the international pancreas transplant registry. Clin Transplant 2005;19:433-55.

22. Vetere A, Choudhary A, Burns SM, Wagner BK. Targeting the pancreatic $\beta$-cell to treat diabetes. Nat Rev Drug Discov 2014;13:278-89.

23. Ikeda Y, Kudva YC. Human fetal pancreatic islet-like structures as source material to treat Type 1 diabetes. Stem Cell Res Ther 2013;4:159-60.

24. Aguayo-Mazzucato C, Bonner-Weir S. Stem cell therapy for Type 1 diabetes mellitus. Nat Rev Endocrinol 2010;6:139-48.

25. Bose B, Shenoy SP, Konda S, Wangikar P. Human embryonic stem cell differentiation into insulin secreting $\beta$-cells for diabetes. Cell Biol Int 2012;36:1013-20.

26. Raikwar SP, Zavazava N. Differentiation and lineage commitment of murine embryonic stem cells into insulin producing cells. Methods Mol Biol 2013;1029:93-8.

27. Tuch B, Hughes T, Evans M. Encapsulated pancreatic progenitors derived from human embryonic stem cells as a therapy for insulindependent diabetes. Diabetes Metab Res Rev 2011;27:928-32.

28. Ber I, Shternhall K, Ohanuna Z, Goldberg I. Functional, persistent, and extended liver to pancreas trans differentiation. J Biol Chem 2003;278:31950-7.

29. Soranna D, Scotti L, Zambon A, Bosetti C, Grassi G, Catapano A. Cancer risk associated with use of metformin and sulfonylurea in Type 2 diabetes: A meta-analysis. Oncologist 2012;17:813-22.

30. Lu J, Herrera PL, Carreira C, Bonnavion R. Alpha cell-specific menlablation triggers the trans differentiation of glucagon expressing cells and insulinoma development. Gastroenterology 2010;138:1954-65.

31. Rao MS, Dwivedi RS, Subbarao V, Usman MI, Scarpelli DG, 
Nemali MR, et al. Almost total conversion of pancreas to liver in the adult rat: A reliable model to study trans differentiation. Biochem BioBiophys Res Commun 1988;156:131-6.

32. Shen CN, Slack JM, Tosh D. Molecular basis of trans differentiation of pancreas to liver. Nat Cell Biol 2000;2:879-87.

33. Lardon J, De Breuck S, Rooman I, Van Lommel L, Kruhoffer M, Orntoft $\mathrm{T}$, et al. Plasticity in the adult rat pancreas: Trans differentiation of exocrine to hepatocytelike cells in primary culture. Hepatology 2004;39:1499-507.

34. Lardon J, Huyens N, Rooman I, Bouwens L. Exocrine cell trans differentiation in dexamethasone-treated rat pancreas. Virchows Arch 2004:444:61-5.

35. Crasto W, Jarvis J, Khunti K. New insulins and new insulin regimens: A review of their role in improving glycaemic control in patients with diabetes. Postgrad Med J 2009;85:257-67.

36. Henry RR, Gumbiner B, Ditzler T. Intensive conventional insulin therapy for Type II diabetes. Metabolic effects during a 6-mo outpatient trial. Diabetes Care 1993;16:21-31.

37. Si Y, Zhao Y, Hao H, Liu J, Guo Y. Infusion of mesenchymal stem cells ameliorates hyperglycemia in Type 2 diabetic rats: Identification of a novel role in improving insulin sensitivity. Diabetes 2012;61:1616-162.

38. Xiang AH, Peters RK, Kjos SL. Effect of pioglitazone on pancreatic $\beta$-cell function and diabetes risk in Hispanic women with prior gestational diabetes. Diabetes 2006;55:517-22.

39. Uwaifo GI, Ratner RE. Differential effects of oral hypoglycaemic agents on glucose control and cardiovascular risk. Am J Cardiol 2007;99:51B-67.

40. Nathan DM, Buse JB, Davidson MB. Medical management of hyperglycemia in type 2 diabetes mellitus: A consensus algorithm for the initiation and adjustment of therapy. Diabetologia 2009;52:17-30.

41. Hasslacher C. Safety and efficacy of repaglinide in Type 2 diabetic patients with and without impaired renal function. Diabetes Care 2003;26:886-91.

42. Blicklé JF. Meglitinide analogues: A review of clinical data focused on recent trials. Diabetes Metab 2006;32:113-20.

43. Ceriello A. The post-prandial state and cardiovascular disease: Relevance to diabetes mellitus. Diabetes Metab Res Rev 2000;16:125-32.

44. Yki-Jarvinen H. Thiazolidinediones. N Engl J Med 2004;351:1106-18.

45. Ye JM, Dzamko N, Cleasby ME. Direct demonstration of lipid sequestration as a mechanism by which rosiglitazone prevents fattyacid-induced insulin resistance in the rat: Comparison with metformin. Diabetologia 2004:47:1306-13

46. Dabhi AS, Bhatt NR, Shah MJ. Voglibose: An alpha glucosidase inhibitor. J Clin Diagn Res 2013;7:3023-27.

47. Bruin JE, Erener S, Vela J, Hu X, Johnson JD, Kurata HT, et al. Characterization of polyhormonal insulin-producing cells derived in vitro from human embryonic stem cells. Stem Cell Res 2014;12:194-8.

48. Zhou J, Su P, Li D, Tsang S, Duan E. High-efficiency induction of neural conversion in human ESCs and human induced pluripotent stem cells with a single chemical inhibitor of transforming growth factor beta superfamily receptors. Stem Cells 2010; 28:1741-50.

49. Heffernan C, Sumer H, Verma PJ. Generation of clinically relevantm "induced pluripotent stem" (iPS) cells. J Stem Cells 2011;6:109-27.

50. Gitt AK, Bramlage P, Binz C, Krekler M, Deeg E. Prognostic implications of DPP-4 inhibitor vs. sulfonylurea use on top of metformin in a real world setting - results of the 1 year follow-up of the prospective Dia regis registry. Int J Clin Pract 2001;67:1005-14.

51. Ahren B. Dipeptidyl peptidase-4 inhibitors: Clinical data and clinical implications. Diabetes Care 2007;30:1344-50.

52. Lambeir AM, Durinx C, Scharpé S. Dipeptidyl-peptidase IV from bench to bedside: An update on structural properties, functions, and clinical aspects of the enzyme DPP IV. Crit Rev Clin Lab Sci 2003;40:209-94.

53. Barnett A. DPP-4 inhibitors and their potential role in the management of Type 2 diabetes. Int J Clin Pract 2006;60:1454-70.

54. Pawlak R. Vegetarian diets in the prevention and management of diabetes and its complications. Diabetes Spectr 2017;30:82-8.

55. Abdelsaid M, Williams R, Hardigan T, Ergul A. Linagliptin attenuates diabetes induced cerebral pathological neovascularisation in a blood glucose independent manner: Potential role of ET-1. Life Sci 2016;159:83-9.

56. Neumillar J. Review of linagliptin for the treatment of Type 2 diabetes mellitus. Clin Ther 2012;34:993-1005.

57. Sena CM, Bento CF, Pereira P. Diabetes mellitus: New challenges and innovative therapies. EMPA J 2010;1:138-63.

58. Olokoba AB, Obateru OA, Olokoba LB. Type 2 diabetes mellitus: A review of current trends. Oman Med J 2012;27:269-73.

59. Chaudhury A, Duvoor C, Dendi VS, Krleti S, Chadaa A, Ravilla R, et al. Clinical review of antidiabetic drugs: Implications for Type 2 diabetes mellitus management. Front Endocrinol 2017;8:1-12.

60. Abdulazeez SS. Diabetes treatment: A rapid review of the current and future scope of stem cell research. Saudi Pharm J 2015;23:333-40.

61. Piero MN, Nzaro GM, Njagi JM. Diabetes mellitus-a devastating metabolic disorder. Asian J Biomed Pharm 2014;4:1-7.

62. Adapa D, Sarangi TK. A review on diabetes mellitus: Complications, management and treatment modalities. Research and reviews. J Med Health Sci 2015;4:1-17.

63. Baynest HW. Classification, pathophysiology, diagnosis and management of diabetes mellitus. J Diabetes Metab 2015;6:1-9.

64. Penalver JJ, Timon IM, Collantes CS, Gomez FJ. Update on the treatment of Type 2 diabetes mellitus. World J Diabetes 2016;7:354-95.

65. Khan SE, Cooper ME, Prato SD. Pathophysiology and treatment of Type 2 diabetes: Perspectives on the past, present and future. Lancet 2014;383:1068-83

66. Liebl A, Khunti K, Beltran DO, Yale JF. Health economic evaluation of Type 2 diabetes mellitus: A clinical practical focused review. Clin Med Insights J Endocrinol Diabetes 2015;8:13-9.

67. Mukhopadhyay P, Maity S, Mandal S, Chakraborti AS, Prajapati AK, Kundu PP. Preparation, characterization and in vivo evaluation of $\mathrm{pH}$ sensitive, safe Quercetin succinylated Chitosan alginate core shell corona nanoparticles for diabetes treatment. Carbohydr Polym 2017;182:42-51.

68. Nathan DM. Adjunctive treatment for Type I diabetes. N Engl J Med 2017;377:2390-91.

69. Ulla A, Khan A, Khan I. Diabetes mellitus and oxidative stress-a concise review. Saudi Pharm J 2016;24:547-53.

70. Baliga V, Sapsford R. Diabetes mellitus and heart failure-an overview of epidemiology and management. Diab Vasc Dis Res 2009;6:164-71.

71. Harikumar K, Kumar BK, Hemalatha GJ, Kumar MB, Lado SF. A review on diabetes mellitus. Int J Novel Trends Pharm Sci 2015;5:201-17.

72. Deshmuk CD, Jain A. Diabetes mellitus: A review. Int J Pure Appl Biosci 2015;3:224-30

73. Clarke C. Oral therapy in Type 2 diabetes: Pharmacological properties and clinical use of currently available agents. Diabetes Spectrum 1998;11:211-21.

74. Kharroubi AT, Darwish HM. Diabetes mellitus: The epidermic of the century. World J Diabetes 2015;6:850-67.

75. Ferrannini E, Muscelli E, Frascerra S, Baldi S, Mari A. Metabolic response to sodium-glucose co transporter 2 inhibition in Type 2 diabetic patients. J Clin Invest 2014;124:499-8 